\title{
Silicone Resin Applications for Ceramic Precursors and Composites
}

\author{
Masaki Narisawa \\ Graduate School of Engineering, Osaka Prefecture University / 1-1, Gakuen-Cho, Naka-Ku, Sakai \\ 599-8531, Japan; E-Mail: nar@mtr.osakafu-u.ac.jp; Tel.: +81-72-254-9312; Fax: +81-72-254-9912
}

Received: 30 April 2010 / Accepted: 24 May 2010 / Published: 2 June 2010

\begin{abstract}
This article reviews the applications of silicone resins as ceramic precursors. The historical background of silicone synthesis chemistry is introduced to explain the production costs and supply availability of various silicones. Thermal degradation processes of silicones are classified in terms of the main chain structure and cyclic oligomer expulsion process, which determine the resulting ceramic yield and the chemical composition. The high temperature decomposition of Si-O-C beyond $1,400{ }^{\circ} \mathrm{C}$ in an inert atmosphere and formation of a protective silica layer on material surfaces beyond $1,200{ }^{\circ} \mathrm{C}$ in an oxidative atmosphere are discussed from the viewpoints of the wide chemical composition of the Si-O-C materials. Applications of the resins for binding agents, as starting materials for porous ceramics, matrix sources with impregnation, fiber spinning and ceramic adhesions are introduced. The recent development of the process of filler or cross-linking agent additions to resin compounds is also introduced. Such resin compounds are useful for obtaining thick coatings, MEMS parts and bulk ceramics, which are difficult to obtain by pyrolysis of simple organometallic precursors without additives.
\end{abstract}

Keywords: silicones; ceramic precursors; silicon oxycarbides; silicon chemistry; high temperature reaction; composites

\section{Introduction}

The polymer precursor method has been mainly developed in the field of inorganic fibers. Carbon fibers with high strength were developed in the early years, and silicon carbide fibers were invented in 1970s [1,2]. The high heat resistance of SiC fibers, even in an oxidative atmosphere, promoted the synthesis chemistry of various ceramic precursors, like polycarbosilanes, polysilazanes and the 
recently successful polyborosilazanes $[3,4]$. On the other hand, the high temperature resistance of ceramic fibers derived from polycarbosilanes is being continuously improved, even at present [5-8]. Such advanced $\mathrm{SiC}$ based fibers are mainly used as reinforcements in ceramic matrix composites with extremely high heat resistance.

On the other hand, sol-gel methods for oxide base ceramic synthesis have been developed over the past few decades. Various alkoxides are now commercially available, and papers on the theme of solgel science and technology are being published at a rate of at least 4,000 per year.

When we contemplate such a situation, it is evident that the combination of carbide base ceramics and oxide base ceramics by some chemical technique will be a great issue, which will be final target of the organic-inorganic hybridization process. We, however, remember simultaneously that such hybridization processes have already been accomplished with great success many years ago. Just around the time of World War II, various silicone polymers, the polysiloxanes, were synthesized on a large scale and widely commercialized. They are available as electric insulator coatings, surface treatments for glass materials, heat resistant oils and chemically stable elastomers. Now such products are highly sophisticated industrial commodities, and we often forget the chemical background of the various commercialized silicone resins. It is a shame that the role of silicones in ceramic technology is reduced to that of being somewhat muddy additives for shaping the starting materials before the sintering process. Here, I tried to shed light again on the classic silicone polymer science, which is quite fundamental in organometallic chemistry and high temperature organic - inorganic reactions. Recent activity in the field and renewed interests in Si-O-C materials correctly indicate the great importance of the modern silicones as ceramic precursors.

\section{Historical Background of Silicone Resin Production $[9,10]$}

Silicon is industrially produced at present on a tremendous scale. The origin of silicon is high purity mineral silica sand. Such silica sand is typically reduced by carbon in an electric arc furnace at $3,000{ }^{\circ} \mathrm{C}$. The silicon obtained, of $98-99 \%$ purity, is called "metal-grade silicon". Besides the uses in the electronics and silicone polymer industry, such metal-grade silicon is used as an important component in various alloys of $\mathrm{Fe}, \mathrm{Al}$ or $\mathrm{Mg}$.

For the uses in electronics, the metal grade silicon is reacted with $\mathrm{SiCl}_{4}$ and hydrogen to yield $\mathrm{HSiCl}_{3}$. This compound is a transparent liquid with a boiling point of $31.8^{\circ} \mathrm{C}$. The liquid nature of $\mathrm{HSiCl}_{3}$ means that the compound can be distilled for purification. After the distillation, reduction by hydrogen and the Czochralski process, a single crystal of silicon with extreme high purity is obtained. The unique properties of the pure silicon, such as its semi conductive nature, acceptance of doping and formation of insulating silica layers on the surface during oxidation, are presently well known. The application of Si for solar cells is increasing its importance in recent times.

$\mathrm{SiCl}_{4}$ is an important recycled product in the pure silicon industry. $\mathrm{SiCl}_{4}$ is also useful for the synthesis of various organosilicon compounds. Kipping systematically investigated organosilicon monomers and polymers derived from $\mathrm{SiCl}_{4}$. The first step is the reaction of a $\mathrm{SiCl}_{4}-$ Grignard reagent ( $\mathrm{RMgBr}$ ). After the reaction, $\mathrm{Si}-\mathrm{Cl}$ bonds are substituted by Si-R bonds. In the case of $\mathrm{C}_{2} \mathrm{H}_{5} \mathrm{MgBr}$, the chemical reaction is expressed by a following equation; 


$$
\mathrm{SiCl}_{4}+\mathrm{C}_{2} \mathrm{H}_{5} \mathrm{MgBr} \rightarrow \mathrm{Si}\left(\mathrm{C}_{2} \mathrm{H}_{5}\right) \mathrm{Cl}_{3}+\mathrm{MgBrCl}
$$

Of course, the Grignard reagent attacks not only the $\mathrm{Si}-\mathrm{Cl}$ bonds in $\mathrm{SiCl}_{4}$, but also the $\mathrm{Si}-\mathrm{Cl}$ in $\mathrm{Si}\left(\mathrm{C}_{2} \mathrm{H}_{5}\right) \mathrm{Cl}_{3}$ and $\mathrm{Si}\left(\mathrm{C}_{2} \mathrm{H}_{5}\right)_{2} \mathrm{Cl}_{2}$. Therefore, the products derived from $\mathrm{SiCl}_{4}-\mathrm{C}_{2} \mathrm{H}_{5} \mathrm{MgBr}$ combinations are often mixtures of various $\mathrm{Si}\left(\mathrm{C}_{2} \mathrm{H}_{5}\right)_{\mathrm{x}} \mathrm{Cl}_{4-\mathrm{x}}$ species. Each compound must be isolated from the mixture by fractional distillation.

Kipping also found that the isolated organosilicon compounds with $\mathrm{Si}-\mathrm{Cl}$ bonds easily reacted with water. In the case of $\mathrm{R}_{2} \mathrm{SiCl}_{2}$ including $\mathrm{Si}\left(\mathrm{C}_{2} \mathrm{H}_{5}\right)_{2} \mathrm{Cl}_{2}$, the reaction is expressed by a following equation:

$$
\mathrm{SiR}_{2} \mathrm{Cl}_{2}+2 \mathrm{H}_{2} \mathrm{O} \rightarrow \mathrm{SiR}_{2}(\mathrm{OH})_{2}+2 \mathrm{HCl}
$$

When $\mathrm{R}$ is not bulky, the silanol groups are simultaneously condensed, and a polysiloxane with a Si-O backbone structure is obtained:

$$
\mathrm{nSiR}_{2}(\mathrm{OH})_{2} \rightarrow\left(-\mathrm{SiR}_{2}-\mathrm{O}-\right)_{\mathrm{n}}+\mathrm{nHCl}
$$

Some part of the silanols remains as terminal groups, and some oligosiloxanes with ring structures can also be obtained in the resulting mixtures. The first silicone resin, reported by Kipping as a "gluelike" product, did not however attract any kind of industrial attention in those days.

On the other hand, the polymeric nature of these "glue-like" silicones attracted the attention of Hyde and related groups at Corning Glass Works. The company developed the industrial process for silicone resin production on the basis of the $\mathrm{SiCl}_{4}$ - Grignard reagent combination, and opened the doors to silicone resin commercialization. The silicone resins were found to be highly compatible with glass materials. Utilization as binders for glass fibers and scratch resistant coatings on glass plates was promoted. The main silicone investigated by Hyde was a kind of polyethylphenylsiloxane (PEPhS).

The synthesis of PEPhS with using Grignard reagent is, however, a multi-step process. Grignard reagents are highly flammable, and the synthesis requires a large amount of metallic magnesium. The silicone thus obtained is rather special and a little far from conventional plastic, like polyethylene, polyamide or phenolic resins, widely produced from petroleum industry raw materials.

In order to overcome such economical and industrial problems, Rochow developed at General Electric a direct synthesis process for organosilicon monomers without the aid of $\mathrm{Mg}$ in 1940. This was essential progress in the silicone industry.

$\mathrm{He}$ got idea from a following reaction of $\mathrm{SiHCl}_{3}$ formation from $\mathrm{Si}$ and $\mathrm{HCl}$ :

$$
\mathrm{Si}(\mathrm{s})+3 \mathrm{HCl}(\mathrm{g}) \rightarrow \mathrm{SiHCl}_{3}(\mathrm{~g})+\mathrm{H}_{2}(\mathrm{~g})
$$

In the Rochow process, $\mathrm{CH}_{3} \mathrm{Cl}$ was introduced in a reaction column instead of $\mathrm{HCl}$, and grains of $\mathrm{Cu}-\mathrm{Si}$ alloy were loaded in the column. $\mathrm{Cu}$ was expected to act as a catalyst. A liquid product, a mixture of methylchlorosilanes, is obtained by the following reaction:

$$
\begin{aligned}
& \text { Excess } \mathrm{CH}_{3} \mathrm{Cl}(\mathrm{g})+\mathrm{Si}(\mathrm{s}) \rightarrow \mathrm{Si}\left(\mathrm{CH}_{3}\right)_{2} \mathrm{Cl}_{2}(\mathrm{~L})+\mathrm{Si}\left(\mathrm{CH}_{3}\right) \mathrm{Cl}_{3}(\mathrm{~L})+\mathrm{SiHCl}_{3}(\mathrm{~g}, \mathrm{~L})+ \\
& \mathrm{SiH}\left(\mathrm{CH}_{3}\right) \mathrm{Cl}_{2}(\mathrm{~L})+\mathrm{Si}\left(\mathrm{CH}_{3}\right)_{3} \mathrm{Cl}(\mathrm{L})+\mathrm{SiCl}_{4}(\mathrm{~L})
\end{aligned}
$$

This is intrinsically a gas-solid reaction. Thus, continuous operation is possible by adjusting the rate of introduction of $\mathrm{CH}_{3} \mathrm{Cl}$ gas, $\mathrm{Si}$, and $\mathrm{Cu}$ powders into a reactor. By fractional distillation, each compound can be isolated with high purity. $\mathrm{Si}\left(\mathrm{CH}_{3}\right)_{2} \mathrm{Cl}_{2}$ has the highest boiling point, while $\mathrm{Si}\left(\mathrm{CH}_{3}\right)_{4}$ has the lowest boiling point, except for the starting $\mathrm{CH}_{3} \mathrm{Cl}$ (Table 1). $\mathrm{Si}\left(\mathrm{CH}_{3}\right)_{2} \mathrm{Cl}_{2}$ is the most valuable 
component in the obtained mixture, because it forms linear Si-O-Si chains after the hydrolysis. Any kind of methylchrolosilanes are, however, useful for tailoring silicone resins, oils, greases, rubbers and varnishes.

Table 1. Boiling points of methylchlorosilanes found in the Rochow process product.

\begin{tabular}{|c|c|}
\hline Compound & Boiling Point $\left({ }^{\circ} \mathbf{C}\right)$ \\
\hline $\mathrm{CH}_{3} \mathrm{Cl}$ & -24.2 \\
$\left(\mathrm{CH}_{3}\right)_{4} \mathrm{Si}$ & 27.5 \\
$\mathrm{HSiCl}_{3}$ & 31.8 \\
$\left(\mathrm{CH}_{3}\right) \mathrm{HSiCl}_{2}$ & 40.7 \\
$\left(\mathrm{CH}_{3}\right)_{3} \mathrm{SiCl}$ & 57.3 \\
$\mathrm{SiCl}_{4}$ & 57.6 \\
$\left(\mathrm{CH}_{3}\right) \mathrm{SiCl}_{3}$ & 65.7 \\
$\left(\mathrm{CH}_{3}\right)_{2} \mathrm{SiCl}_{2}$ & 70.0 \\
\hline
\end{tabular}

On the other hand, phenyl chlorosilanes are also useful monomers in the silicone industry. It is possible to synthesize phenyl chlorosilanes by direct reaction of chlorobenzene $\left(\mathrm{C}_{6} \mathrm{H}_{5} \mathrm{Cl}\right)$ and the $\mathrm{Si}-\mathrm{Cu}$ alloy. Higher temperature $\left(400-500{ }^{\circ} \mathrm{C}\right)$ and a larger amount of $\mathrm{Cu}$ content $(30$ mass \%) are however required.

Compared to such direct syntheses using the $\mathrm{Si}-\mathrm{Cu}$ alloy, the following dehydration or dehydrochloration reaction is more efficient and widely available for the production of phenyl chlorosilanes and vinyl chlorosilanes:

$$
\begin{gathered}
\mathrm{C}_{6} \mathrm{H}_{6}+\mathrm{HSiCl}_{3} \rightarrow \mathrm{C}_{6} \mathrm{H}_{5} \mathrm{SiCl}_{3}+\mathrm{H}_{2} \\
\mathrm{CH}_{2}=\mathrm{CHCl}+\mathrm{HSiCl}_{3} \rightarrow \mathrm{CH}_{2}=\mathrm{CHSiCl}_{3}+\mathrm{HCl}
\end{gathered}
$$

The introduced $\mathrm{HSiCl}_{3}$ is obtained by the fractional distillation of the product of Rochow process, or is obtained from the products in the pure silicon industry. From a cursory glance at such chemical processes, we can get a sense of how polymers so unique as the silicones have been widely produced at relatively low cost, and what kind of silicone is more popular from the viewpoint of the industry.

\section{Thermal Degradation of Linear Silicones}

Silicone is superior in heat and chemical resistance as compared with ordinary polymers. Silicone oils are necessary component in high vacuum systems, and we often see elastic silicone rubber materials in medical and chemical uses. In most cases, linear polysiloxane or partly cross-linked polysiloxane were used in commercialized products. Si-O bonds in siloxane chain are flexible as compared with $\mathrm{C}-\mathrm{C}$ bonds, and silicones intrinsically maintain their liquid nature over a wide temperature region. For example, a glass transition temperatures of polydimethylsiloxane (PDMS) or polymethylphenylsiloxane $(\mathrm{PMPhS})$ are $-127^{\circ} \mathrm{C}$ and $-86^{\circ} \mathrm{C}$, respectively $[11,12]$.

Thermal degradation of PDMS with complete linear structure proceeds at $290-600{ }^{\circ} \mathrm{C}$ with formation of cyclic oligomers. In an inert atmosphere or vacuum, a trimer $\left(\mathrm{Si}_{3} \mathrm{O}_{3}\left(\mathrm{CH}_{3}\right)_{6}\right)$ and tetramer $\left(\mathrm{Si}_{4} \mathrm{O}_{4}\left(\mathrm{CH}_{3}\right)_{8}\right)$ are the major components in the decomposition gas. Chemical species with higher molecular weight, like a hexamer and an octamer, are also found as components. Thomas et al. 
proposed an intramolecular cyclization process for the thermal degradation of PDMS [13]. The low activation energy, $40 \mathrm{kcal} / \mathrm{mol}$, suggests the existence of a stable transition state, which promotes the degradation of the silicone resin. The linear siloxane chains can easily make intramolecular contact because of the flexible nature of the chains and the Si d-orbital interactions. Thus, the degradation proceeds by simultaneous rearrangement of Si-O bonds with expulsion of cyclic oligomers (Figure 1).

Figure 1. Cyclic oligomer (trimer) expulsion mechanism from a polymethylsiloxane chain during thermal decomposition process.

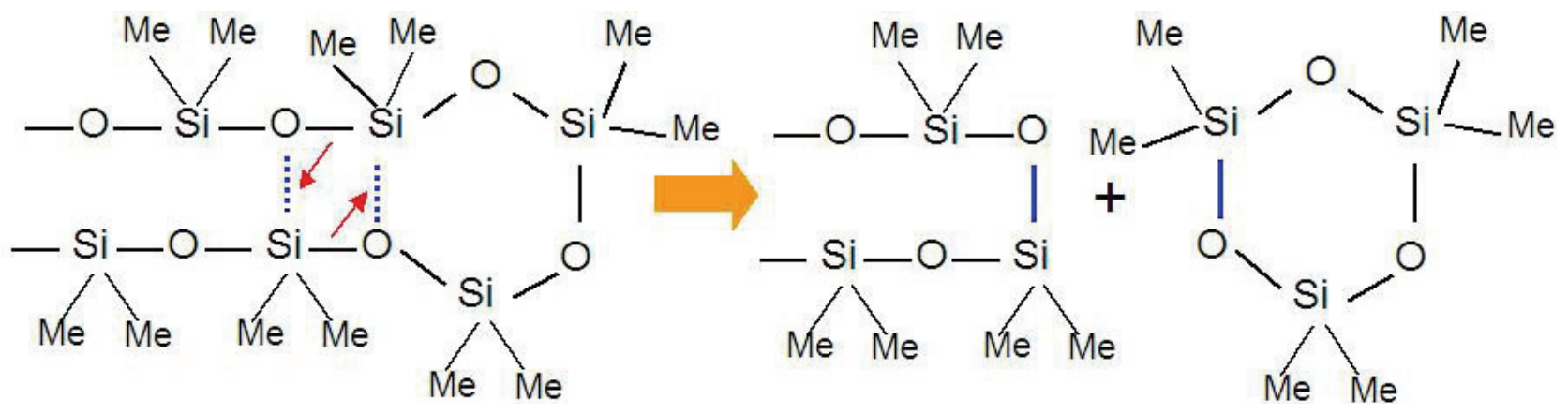

It is interesting that PDMS is obtained not only from hydrolysis of $\left(\mathrm{CH}_{3}\right)_{2} \mathrm{SiCl}_{2}$ but also from ring opening polymerization of the cyclic tetramer $\left(\mathrm{Si}_{4} \mathrm{O}_{4}\left(\mathrm{CH}_{3}\right)_{8}\right)$. In other words, the decomposition process of PDMS is a kind of depolymerization.

In the presence of oxygen, the degradation process of linear silicones becomes complex [14]. In a relatively low temperature region, oxygen acts as a catalyst promoting the scission and rearrangement processes of the Si-O bonds. Thus, the depolymerization process and removal of volatile oligomers occurs at a relatively low temperature $\left(290{ }^{\circ} \mathrm{C}\right)$ as compared with that in an inert atmosphere $\left(400{ }^{\circ} \mathrm{C}\right)$. The residual siloxane is, however, condensed by oxidative cross-linking, which reduces the mass loss rate in the last stage of the decomposition. Such oxidation cross-linking is possibly triggered by the formation of radicals on side groups, which trap oxygen and form peroxides, which sometimes accelerate the cross-linking and sometimes accelerate the depolymerization process. In an oxidative atmosphere, ca. 10 mass $\%$ of silica is obtained as a result of the competition between oxidative crosslinking and volatilization of oligomers.

Even in an inert atmosphere, an inorganic residue is sometimes obtained after pyrolysis with very high heating rates [14]. Perhaps, condensation of low molecular weight oligomers, which cannot be diffused out, takes place. The obtained glassy black product is thought to possess Si-O-C composition.

The decomposition processes of various linear polymers composed of $-\mathrm{SiR}_{1} \mathrm{R}_{2}-\mathrm{O}-,-\mathrm{Si}\left(\mathrm{CH}_{3}\right)_{2}-\mathrm{CH}_{2}-$ $\mathrm{Si}\left(\mathrm{CH}_{3}\right)_{2}-\mathrm{O}$ - or - $\mathrm{Si}\left(\mathrm{CH}_{3}\right)_{2}-\mathrm{CH}_{2}-\mathrm{CH}_{2}-\mathrm{Si}\left(\mathrm{CH}_{3}\right)_{2}-\mathrm{O}$ - units were also investigated by Thomas et al. [15]. Thermal degradation proceeds via the depolymerization reaction and the mechanism is similar to that of the usual linear polysiloxanes like PDMS. The major gaseous products are cyclic trimers and tetramers.

Introduction of phenyl groups in silicone polymers usually increases the onset temperature of mass loss of polysiloxanes [15-17]. The residual mass at $1,000^{\circ} \mathrm{C}$, however, does not increase, because of evolution of benzene, toluene and cyclic siloxane oligomers during higher temperature degradation processes at $400-600{ }^{\circ} \mathrm{C}$. Siloxane oligomers with phenyl groups are absent in the gaseous products. 
Perhaps, phenyl side groups are decomposed by the radical reaction, and the cyclic oligomer expulsion follows such side group decomposition processes. When the chain is flexible, anyway, it is likely difficult to avoid the cyclic oligomer expulsion caused by the $\mathrm{Si}-\mathrm{O}$ and $\mathrm{Si}-\mathrm{C}$ bond rearrangements during the thermolysis.

\section{Increased Ceramic Yield in Cross-Linked Silicones}

In order to increase the ceramic yield of silicones, a dense cross-linked structure, which prevents the bond rearrangement process during heating, is necessary. As compared with the $\mathrm{C}-\mathrm{O}\left(351.5 \mathrm{~kJ} \mathrm{~mol}^{-1}\right)$, C-C bond $\left(347.7 \mathrm{~kJ} \mathrm{~mol}^{-1}\right)$ and $\mathrm{C}-\mathrm{Si}$ bonds $\left(290.0 \mathrm{~kJ} \mathrm{~mol}^{-1}\right)$, the high energy of the Si-O bond $\left(369.0 \mathrm{~kJ} \mathrm{~mol}^{-1}\right)$ is promising for increasing the ceramic yield of silicones. Introduction of vinyl, phenyl groups or acetylene linkages in silicone molecular structure may be also effective for increasing the apparent ceramic yields. The efficiency of such side groups, however, often depends on behavior of "radicals", which sometimes decompose side groups to gaseous product. There is also the concern that during pyrolysis such side groups are converted to free carbon domains, which are not directly incorporated into the inorganic Si-O-C networks.

Zhou et al. introduced $\mathrm{T}$ units in siloxane chains in order to investigate the effect of Si-O cross-linking on the thermal stability [17]. As the content of $T$ units increases, the resulting ceramic yield increases. On the other hand, Mantz et al. investigated thermolysis of polyhedral oligometric silsesquioxane (POSS)-siloxane copolymers [18]. Loss of the cyclic dimethylsiloxane oligomers proceeds at $400{ }^{\circ} \mathrm{C}$, and loss of the silsesquioxane "cage" structure proceeds at $450-650{ }^{\circ} \mathrm{C}$. This means that the incorporated cage structure, composed of complete $\mathrm{T}$ units, is not simply maintained during the heating, and the thermal degradation process in this case is complex, which possibly corresponds to some steric hindrance effect of the cage structure on the main chain rearrangement process.

Burns et al. (Dow Corning) synthesized various cross-linked polysiloxanes by sol-gel methods, and investigated their ceramization process [19]. The starting monomers are $\mathrm{PhSi}(\mathrm{OMe})_{3}, \mathrm{MeSi}(\mathrm{OMe})_{3}$ and $\left(\mathrm{ViMe}_{2} \mathrm{Si}\right)_{2} \mathrm{O}$. After the condensation reactions of the monomers in controlled amounts, the residual $\mathrm{OH}$ groups are terminated by $\mathrm{ViMe}_{2} \mathrm{SiCl}$. An expected application of these silicones is as a sintering aid in the $\mathrm{SiC}$ base ceramics production process. The silicones are also expected to help the molding, pressing, casting and infiltration processes of prepared slurries composed of $\mathrm{SiC}$ grains, silicones and a small amount of solvent. Ceramic yields of the obtained polymers at $1,100{ }^{\circ} \mathrm{C}$ in an inert atmosphere are ca. 65-75 mass\%, while $\mathrm{O} / \mathrm{Si}$ ratios are 1.3-1.4. Carbon contents in these silicones are always controlled at high values. The silicones are converted to amorphous $\mathrm{SiO}_{\mathrm{x}} \mathrm{C}_{\mathrm{y}}$ by pyrolysis at $1,100{ }^{\circ} \mathrm{C}$, and successively converted to $\mathrm{SiC}$ and excess carbon by carbothermic reduction at $1,800{ }^{\circ} \mathrm{C}$ expressed by the following reaction:

$$
\mathrm{SiO}_{\mathrm{x}} \mathrm{C}_{\mathrm{y}} \rightarrow \mathrm{SiC}+\mathrm{xCO}+(\mathrm{y}-\mathrm{x}-1) \mathrm{C}
$$

Residual masses after the carbothermic reduction process are 35-50 mass \%. The yield tends to increase with the increase in the carbon content in the starting Si-O-C. The amount of excess carbon after pyrolysis at $1,800{ }^{\circ} \mathrm{C}$ also increases. $\mathrm{SiC}$ nanocrystallites formed in situ and excess carbon are expected to act as sintering aids for the loaded coarse $\mathrm{SiC}$ grains during high temperature heat treatment. 
Hurwitz et al. carried out systematic studies on the pyrolysis process of polyphenyl-polymethylsilsesquioxane co-polymers, which were synthesized by hydrolytic condensations of $\mathrm{PhSi}(\mathrm{OMe})_{3}$ and $\mathrm{MeSi}(\mathrm{OMe})_{3}$ [20]. The ceramic yields of the co-polymers decreases as the phenyl content in the copolymer increases, while the ceramic yield of polyphenylsilsesquioxne (PPSQ) is ca. $60 \%$, and that of poymethylsilsesquioxane (PMSQ) is ca. $80 \%$. The onset temperatures of mass losses of PPSQ and the co-polymers is $500{ }^{\circ} \mathrm{C}$, while that of PMSQ, with $100 \%$ methyl side groups, is $750{ }^{\circ} \mathrm{C}$.

Oxidation resistance of Si-O-C materials derived from co-polymers of 30P, 50P and 70P (P means a phenyl molar content to phenyl + methyl groups in the co-polymer) were also investigated [20]. Carbon burning usually proceeds in the temperature range of $600-1,000{ }^{\circ} \mathrm{C}$. As the phenyl group content decreases, however, the oxidation resistance of the $\mathrm{Si}-\mathrm{O}-\mathrm{C}$ materials increases, which is indicated by slow mass loss rate in a TG curve.

Brewer et al. (Dow Corning) investigated the oxidation resistance of Si-O-C materials derived from $\mathrm{PhSi}(\mathrm{OMe})_{3}, \mathrm{MeSi}(\mathrm{OMe})_{3}$ and $\left(\mathrm{ViMe}_{2} \mathrm{Si}\right)_{2} \mathrm{O}$ [21]. The oxidation resistance possesses a close relationship to the carbon content in the Si-O-C materials. The Si-O-C materials derived from the copolymer of $0.78 \mathrm{MeSi}(\mathrm{OMe})_{3}$ and $0.22\left(\mathrm{ViMe}_{2} \mathrm{Si}\right)_{2} \mathrm{O}$ (with a chemical composition of $\mathrm{SiO}_{1.35} \mathrm{C}_{1.14}$ ) shows the highest oxidation resistance. Even after $500 \mathrm{~h}$ treatment in air at $1,200{ }^{\circ} \mathrm{C}$, the residual carbon content exceeds half the original content. It is regrettable that the observed oxidation resistance is not based on complete quantitative estimation, because the specific surface area of prepared powderlike sample is not defined, although Brewer observed formation of a transparent oxide layer on the SiO-C materials after the oxidation treatment, which should protect inner materials from rapid oxidation.

The $\mathrm{O} / \mathrm{Si}$ molar ratios in the densely cross-linked silicones, described in this section, are expected to be 1.0-1.5 before pyrolysis. Wilson et al. (Dow Corning) investigated the chemical compositions of a series of Si-O-C materials derived from cross-linked silicones [22]. The starting O/Si ratios are roughly maintained when the ceramic yields of the resins are high. In some cases with relatively low ceramic yields, the $\mathrm{O} / \mathrm{Si}$ ratios are increased during pyrolysis. Such an increase in $\mathrm{O} / \mathrm{Si}$ ratio can be simply explained by removal of a large amount of siloxane oligomer during pyrolysis, because the $\mathrm{O} / \mathrm{Si}$ of the cyclic siloxane oligomers is 1.0 . The decrease in the $\mathrm{O} / \mathrm{Si}$ ratio during pyrolysis observed in a few cases is difficult to explain. The evolution of the "cage" structure $(\mathrm{O} / \mathrm{Si}$ molar ratio of 1.5$)$ is one mechanism to explain such decreases, but there is no sufficient data indicating the "cage" sublimation during the pyrolysis of the cross-linked silicones. Quite recently, Ionescu et al. reported evolution of octamethyl T8 polyhedral oligosilsesquioxane (POSS) during cross-linked silicone resin pyrolysis [23]. Quantitative estimation of the evolved "cage" amount and influence on total chemical composition of ceramic reside are, however, still ambiguous at present.

In an inert atmosphere, once formed $\mathrm{SiO}_{\mathrm{x}} \mathrm{C}_{\mathrm{y}}$ materials from the silicone resins are considered to be decomposed beyond $1,400{ }^{\circ} \mathrm{C}$. This expectation is based on the carbothermal reduction process of silica-carbon mixtures. In other words, chemical activity of oxygen in the $\mathrm{SiO}_{\mathrm{x}} \mathrm{C}_{\mathrm{y}}$ is assumed to be almost equal to that in silica. If the carbon content in the Si-O-C material is sufficiently high or pyrolysis environment is rather closed, $\mathrm{SiC}$ and excess carbon are formed during the carbothermnal reduction, as shown in Equation (7).

If the carbon content in the Si-O-C material is low or evolved gas from the system easily diffuses out, the gasification of the $\mathrm{Si}-\mathrm{O}-\mathrm{C}$ material shown in the following equation would become dominant: 


$$
\mathrm{SiO}_{\mathrm{x}} \mathrm{C}_{\mathrm{y}} \rightarrow \mathrm{SiO}+(\mathrm{x}-1) \mathrm{CO}+(\mathrm{y}-\mathrm{x}+1) \mathrm{C}
$$

The balance between equations (7) and (8) depends not only on the starting carbon content but also on the partial pressures of $\mathrm{CO}$ and $\mathrm{SiO}$ in the surrounding environments. In addition, vapor phase condensation reactions of $\mathrm{SiO}, \mathrm{CO}$ and $\mathrm{C}$ are known to form various kinds of $\mathrm{SiC}_{-} \mathrm{SiO}_{2}$ whiskers or nano tubes. Thus the whole chemical process depends on the partial pressure of the individual gaseous species present and often becomes quite complex.

On the other hand, the $\mathrm{SiO}_{\mathrm{x}} \mathrm{C}_{\mathrm{y}}$ material is expected to be converted to silica when the partial pressure of oxygen in the heat treatment condition is sufficiently high:

$$
\mathrm{SiO}_{\mathrm{x}} \mathrm{C}_{\mathrm{y}}+(1-\mathrm{x}+2 \mathrm{y}) \mathrm{O}_{2} \rightarrow \mathrm{SiO}_{2}+\mathrm{yCO}_{2}
$$

\begin{tabular}{|c|c|c|c|}
\hline \multirow{2}{*}{ - Methyl group decomposition $\left(600^{\circ} \mathrm{C}\right.$} & \multicolumn{2}{|c|}{$\begin{array}{l}\text { Protective silica layer formation in an } \\
\text { oxidation atmosphere (beyond } 1000^{\circ} \mathrm{C} \text { ) }\end{array}$} & \\
\hline & (1300. & $(1400-1$ & $\left.1600^{\circ} \mathrm{C}\right)$ \\
\hline $\begin{array}{l}\text { Cross-linked silicones } \\
\text { (Methyl side groups) }\end{array}$ & $\begin{array}{l}\text { Si-O-C amorphous } \\
\text { (Low carbon) }\end{array}$ & $\begin{array}{l}\mathrm{SiO}_{2}-\mathrm{SiC}-\mathrm{C} \\
\text { (Low carbon) }\end{array}$ & $\begin{array}{l}\text { Gasification:SiO-CO } \\
\text { (Low residue) }\end{array}$ \\
\hline \multirow{2}{*}{$\begin{array}{l}\text { - Bulky side group decomposition } \\
\text {-"Ring, cage" sublimation? } \\
\text { (450-60 }\end{array}$} & \multicolumn{2}{|c|}{$\begin{array}{l}\text { Incomplete silica layer formation in an } \\
\text { oxidation atmosphere (beyond } 600^{\circ} \mathrm{C} \text { ) }\end{array}$} & \\
\hline & $(1300$. & $(1400$ & $\left.-1600^{\circ} \mathrm{C}\right)$ \\
\hline $\begin{array}{l}\text { Cross-linked silicones } \\
\text { (Bulky side groups) }\end{array}$ & $\begin{array}{l}\text { Si-O-C amorphous } \\
\text { (High carbon) }\end{array}$ & $\begin{array}{l}\mathrm{SiO}_{2}-\mathrm{SiC}-\mathrm{C} \\
\text { (High carbon) }\end{array}$ & $\begin{array}{l}\text { SiC-C } \\
\text { (High residue) }\end{array}$ \\
\hline
\end{tabular}

Figure 2. Various modes of thermal decomposition of silicone resins.

- Bulky side group decomposition

- Cyclic oligomer expulsion

$\left(290-600^{\circ} \mathrm{C}\right)$

Linear silicones

Si-O-C amorphous (Low residue)

Such silica is often formed as a layer on the material surface. The completeness and the efficiency of the formed layer for the material protection also depend on the carbon content in the materials and oxygen activity in the surrounding environment. Figure 2 summarizes the various thermal decomposition modes of silicones or silicone-derived amorphous species. In the low temperature region, the starting chain structure determines the degradation process. In particular, "linear" or "branched" is important. In the high temperature region, the chemical composition and the pyrolysis atmosphere are the major factors which determine the degradation mode. 


\section{Industrially Available Silicone Resins with High Ceramic Yields}

As shown in a previous section, polymethylsilsesquioxane (PMSQ) is a simple and promising ceramic precursor for Si-O-C base materials because of the low carbon content and intrinsic low cost. In early days, however, PMSQ obtained by condensation reactions was not soluble and stable. In 1978, the first soluble PMSQ in resin form was synthesized by Suminoe [24,25]. In his process, $\left(\mathrm{C}_{2} \mathrm{H}_{5}\right)_{3} \mathrm{~N}$ and $\mathrm{MeSiCl}_{3}$ are dissolved in mixed solvent of methylisobutylketone (MIBK) and tetrahydrofuran (THF). The hydrolysis reaction is carried out by adding water dropwise to the solution. After temporary precipitation of a white salt and re-dissolution of the salt by increasing the amount of water, the obtained solution is heat-treated and refluxed at $100-110{ }^{\circ} \mathrm{C}$. After extraction, washing and re-precipitation, a resin with a molecular weight of 9,000 is obtained. It is stable even after one month storage, and soluble in organic solvents like THF or toluene. It is also possible to obtain PMSQ with higher molecular weights. The low molecular weight PMSQ is dissolved in ether with water and $\mathrm{Me}_{3} \mathrm{NHCl}$, and hydrolyzed again by heating at $130{ }^{\circ} \mathrm{C}$ for $4 \mathrm{~h}$. The measured molecular weight of the resin is increased to 100,000 . The solubility is organic solvents is also maintained. Such solubility possibly depends on an amount of the residual $\mathrm{OH}$ groups in the structure, which do not completely disappear after the hydrolysis reactions.

Nowadays, a few kinds of silicone resins are commercialized under the PMSQ name. Wacker-Belsil PMS $\mathrm{MK}^{\mathrm{TM}}$ is available from Wacker Chemie AG. It is white powder with the proposed chemical structure $\left(-\left(\mathrm{CH}_{3}\right) \mathrm{Si}\left(\mathrm{O}_{3 / 2}\right)-\right)_{\mathrm{n}}[26]$. The softening point is $50-60{ }^{\circ} \mathrm{C}$ and the resin accepts the attack of alcohol. Since the PMSQ reported by Suminoe is washable with methanol, the molecular weight of PMS $\mathrm{MK}^{\mathrm{TM}}$ is possibly low and it contains a large amount of $\mathrm{OH}$ groups as compared with the one previously reported.

YR $3370^{\mathrm{TM}}$ is available from Momentive Performance Materials Japan. It is a transparent hard resin that softens at ca. $110^{\circ} \mathrm{C}$. Since the YR3370 ${ }^{\mathrm{TM}}$ is also soluble in ethanol, the structure also probably contains a considerable amount of $\mathrm{OH}$ groups. The hard appearance, however, suggests a higher molecular weight of YR3370 ${ }^{\mathrm{TM}}$ than that of PMS MK ${ }^{\mathrm{TM}}$ powder. The elemental analysis of YR3370 ${ }^{\mathrm{TM}}$ shows the chemical composition of $\mathrm{SiO}_{1.78} \mathrm{C}_{1.22} \mathrm{H}_{3.67}$. The content of carbon is a little high, beyond the expectation based on an assumed [- $\left.\left(\mathrm{CH}_{3}\right) \mathrm{Si}\left(\mathrm{O}_{1.5}\right)-\right]$ unit structure.

Kim et al. used polymer blend or filler loaded YR $3370^{\mathrm{TM}}$ as starting materials for SiC or silicon oxycarbide based porous ceramics [27,28]. Control of the starting porous structure depends on the viscoelastic nature of the resin, which was analyzed in detail by the same group [28]. By adjustment of the conditions, even the melt spinning process is available for YR $3370^{\mathrm{TM}}$ at $130-180{ }^{\circ} \mathrm{C}$. The resin fiber can be converted into oxidation resistant continuous Si-O-C ceramic fibers by adjusting the conditions of metal chloride vapor curing and the pyrolysis conditions [Figures 3 (a) and (b)] [29].

The ceramization of YR3370 ${ }^{\mathrm{TM}}$ was also well characterized [29,30]. While the viscoelastic properties of the commercialized or synthesized PMSQs are various, the ceramization process of PMSQs is not sensitive to the synthesis conditions. Figures 4 (a),(b) shows a TG curve and ${ }^{29} \mathrm{Si}-\mathrm{NMR}$ spectrum of YR $3370^{\mathrm{TM}}$ during the pyrolysis. A $5 \%$ mass loss occurs at $250-300{ }^{\circ} \mathrm{C}$ with cross-linking of $\mathrm{OH}$ groups, and an $8 \%$ mass loss occurs at $600{ }^{\circ} \mathrm{C}$ with evolution of methane. At $1,200{ }^{\circ} \mathrm{C}$, the analyzed chemical composition of the amorphous $\mathrm{Si}-\mathrm{O}-\mathrm{C}$ was $\mathrm{SiO}_{1.5} \mathrm{C}_{0.68}$. The mass loss observed beyond $1,400{ }^{\circ} \mathrm{C}$ corresponds to gasification of Si-O-C. Reaction between a graphite crucible and the 
Si-O-C amorphous possibly enhances the continuous mass loss during the holding at $1873 \mathrm{~K}$. These behaviors in ceramization are consistent with the previous data reported about various PMSQs [20,31].

Figure 3. (a) Screening test on heat resistant ceramic fibers (result of the Si-O-C $\left(\mathrm{SiO}_{1.5} \mathrm{C}_{0.63}\right)$ fiber, $20 \mathrm{~min}$ ) [29]; (b) residual $\mathrm{Si}-\mathrm{O}-\mathrm{C}$ core surrounded by a thick silica layer after continuous $24 \mathrm{~h}$ oxidation at $1,511 \mathrm{~K}$ on the Si-O-C fiber.

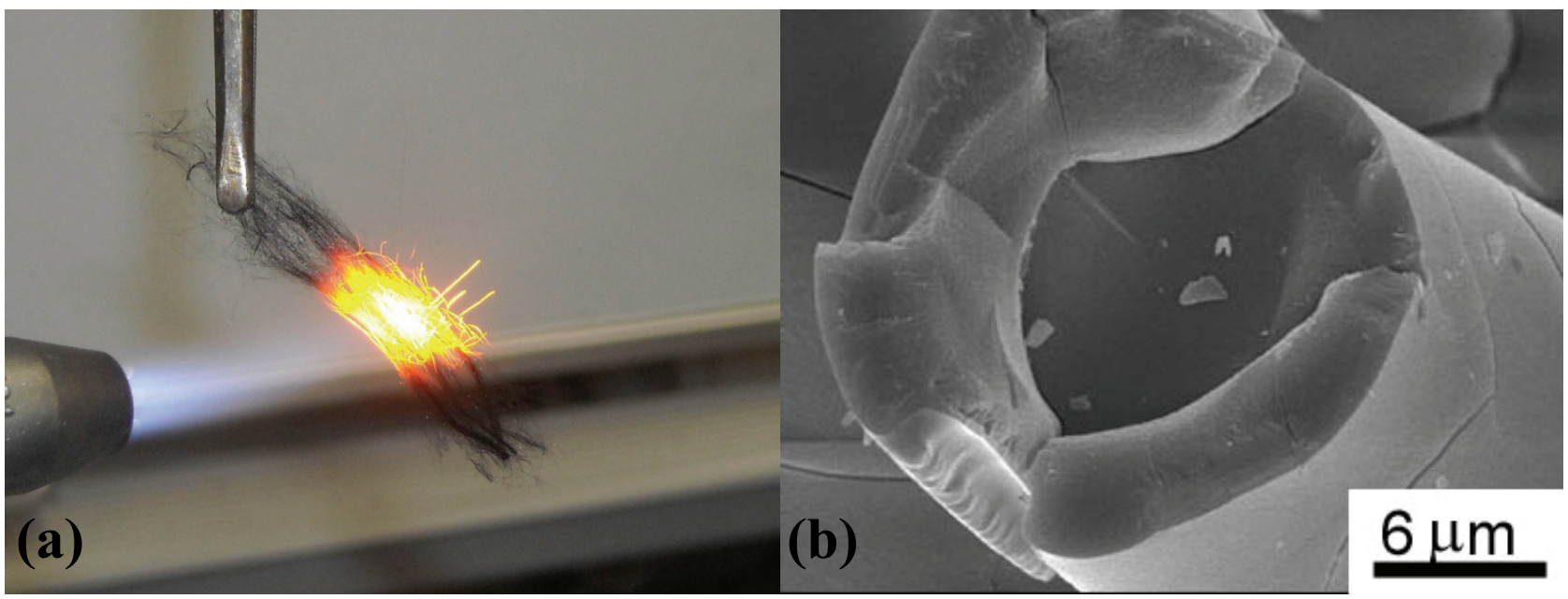

Figure 4. (a) Results of TG analysis on $\mathrm{YR} 3370^{\mathrm{TM}}$ resin in carbon rich atmosphere (10 K/min up to $1473 \mathrm{~K}, 3 \mathrm{~K} / \mathrm{min}$ beyond $1473 \mathrm{~K}$ and holding at $1873 \mathrm{~K}$ for $3 \mathrm{~h}$ ) [29]; (b) ${ }^{29} \mathrm{Si}-\mathrm{NMR}$ spectrum of YR3370 ${ }^{\mathrm{TM}}$ pyrolyzed at various temperatures [30].
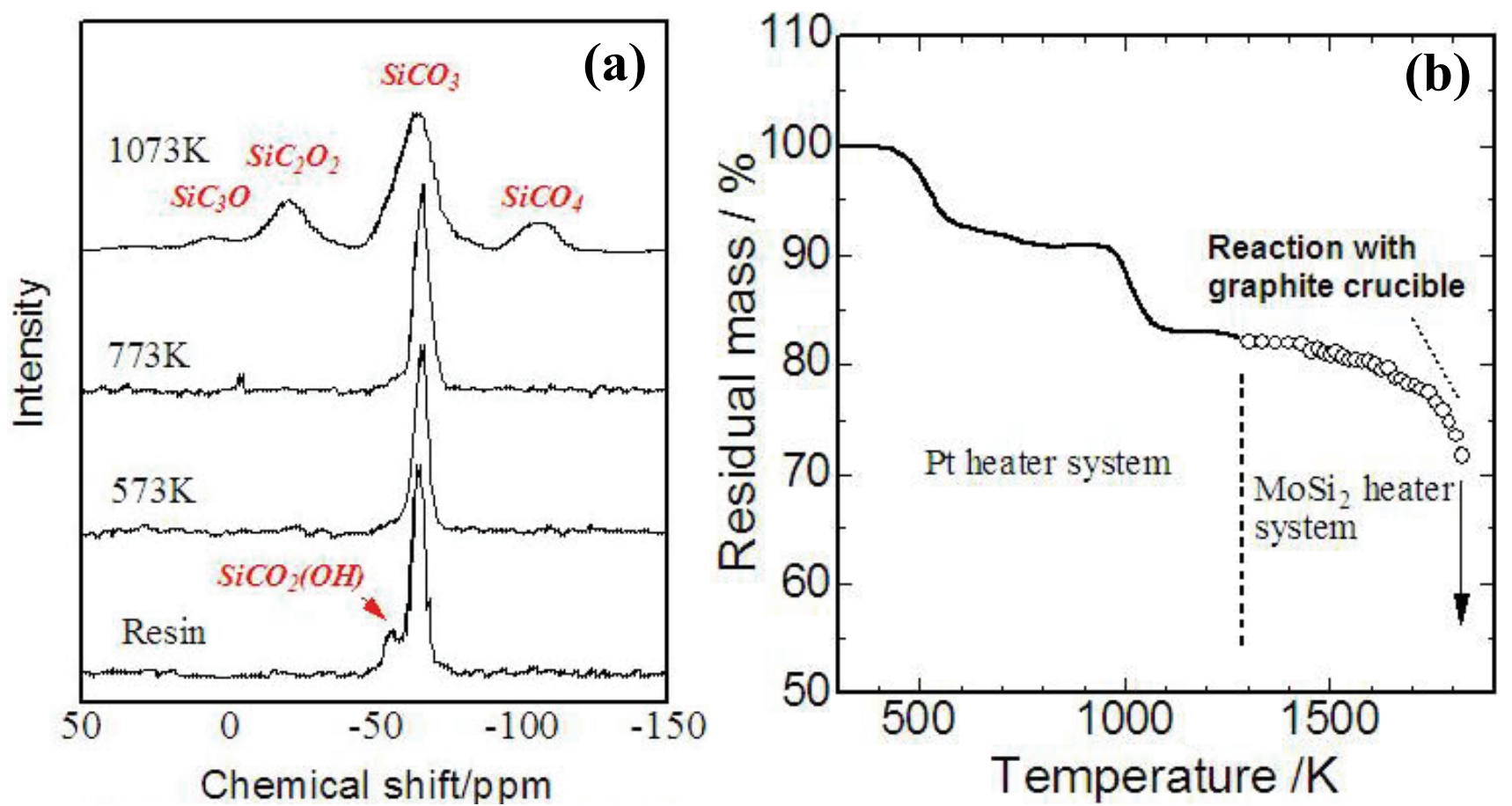

SR $350^{\mathrm{TM}}$, which is a kind of silicone resin with low carbon content and with highly branched structure, is available from General Electric Silicone Products. The resin is synthesized from 2-8\% of dimethyldichlorosilane, $\mathrm{Si}\left(\mathrm{CH}_{3}\right)_{2} \mathrm{Cl}_{2}$, and $92-98 \%$ of methyltrichlorosilane, $\mathrm{Si}\left(\mathrm{CH}_{3}\right) \mathrm{Cl}_{3}$ [32,33]. The resin is softened at $30{ }^{\circ} \mathrm{C}$ and becomes fluid at $90{ }^{\circ} \mathrm{C}$. SR350 ${ }^{\mathrm{TM}}$ is also soluble in most organic solvents 
like toluene, ketones, alcohols and ether. In the pyrolysis of $\mathrm{SR} 350^{\mathrm{TM}}$, a 15 mass \%mass loss is observed up to $200{ }^{\circ} \mathrm{C}$. Perhaps, the amount of the residual hydroxyl groups is high as compared with complete PMSQ resins, and the $\mathrm{OH}$ groups are condensed up to $200{ }^{\circ} \mathrm{C}$ with $\mathrm{H}_{2} \mathrm{O}$ evolution. The ceramic yield in an inert atmosphere is 75 mass $\%$ at $1,000{ }^{\circ} \mathrm{C}$. Oxidation resistance of the Si-O-C materials derived from SR $350^{\mathrm{TM}}$ is also reported in terms of protective silica layer formation on the material surfaces.

Some resins with the PMSQ name are available mainly in the field of cosmetics. Gransil $\mathrm{PSQ}^{\mathrm{TM}}$ is supplied by Grant Industries, and Tospearl ${ }^{\mathrm{TM}}$ ie supplied from Momentive Performance Materials Japan. The molecular structure of Tospearl ${ }^{\mathrm{TM}}$ is possibly similar to that of YR3370 ${ }^{\mathrm{TM}}$, but the shape is often micro spherical and it is insoluble in any solvents. There is no reported ceramization data for these PMSQs.

\section{Application of Silicone Resins for Various Ceramic Products}

Hurwitz reported early studies about the utilization of polysilsesquioxanes (PSQ) in the field of ceramic matrix composites [34,35]. The viscoelastic properties of PSQ copolymers (with $\mathrm{CH}_{3^{-}}, \mathrm{C}_{3} \mathrm{H}_{7^{-}}$ and $\mathrm{C}_{6} \mathrm{H}_{5^{-}}$side groups) were adjusted to make the melt spinning process possible at 70-100 ${ }^{\circ} \mathrm{C}$. The spun fiber accepted UV curing with the decomposition of phenyl side groups. The infiltration and pyrolysis of the co-polymer in $\mathrm{SiC}$ fiber (Nicalon) fabrics was also examined for making heat resistant CMC. In an inert atmosphere, heat resistance of the formed CMC up to $1,400{ }^{\circ} \mathrm{C}$ was suggested. The pyrolysis of such copolymers including phenyl groups, however, must accept the increased amount of residual carbon in the obtained Si-O-C materials. It is probably the weak point of the process because the high carbon content often diminishes the oxidation resistance of the Si-O-C amorphous obtained after pyrolysis.

The synthesis of heat resistant ceramic foams by using the viscoelastic nature of silicone resins was widely examined. Colombo et al. reported Si-O-C ceramic foam synthesis from the mixtures of SR350, monomers of polyurethane (polyols and diamines) and a blowing agent $\left(\mathrm{CH}_{2} \mathrm{Cl}_{2}\right.$ : b.p. of $\left.40{ }^{\circ} \mathrm{C}\right)$ [36] Since the silicone resin mass ratio to polyurethane (PU) was 1.0, SR350 was expected to be expanded as concentrated polymer solution and solidified with PU during the foaming process. The reaction of silanol groups in SR350 with amino groups in the diamine, however, was possible and the resulting foaming process may be more complex. Anyway, the silicone resin network displayed good compatibility with PU during the whole process, because the tailored foam structure was maintained after pyrolysis up to $1473 \mathrm{~K}$. The Si-O-C ceramic foams with a bulk density of $0.1-0.4 \mathrm{gcm}^{-3}$ and cell size of 300-600 $\mathrm{mm}$ were obtained. On the other hand, direct foaming process of preceramic polymers (PCS-YR3370) by using $\mathrm{CO}_{2}$ gas saturation-desaturation process was reported by Kim et al. [37]. $\mathrm{CO}_{2}$ has a critical point close to room temperature and is easily dissolved in polymer networks by loading under high pressure. By rapidly dropping the $\mathrm{CO}_{2}$ pressure, a number of fine cells $(<10 \mu \mathrm{m})$ were formed in the resin matrix. After the pyrolysis, the Si-O-C microcellular structure was obtained. Another way to achieve such a Si-O-C microcellular structure was the use of sacrificial fillers of PMMA microbeads [38]. In this method, control of long range pore order is possible in principle by packing of microbeads. On the other hand, Zeschky et al. reported the control of porosity gradient in precursor foam by adjusting the viscosity of the melted precursor media [39]. A major component of 
the foamed media was a kind of methyl-phenyl-silsesquioxane (Sirless H44, Wacker Chemie). The media, however, contains considerable amounts of $\mathrm{Si}$ and $\mathrm{SiC}$ particles dispersed in the resin melt. Therefore, the whole thermoplastic-thermosetting nature during the heating and holding was complex. Bubbles of $\mathrm{H}_{2} \mathrm{O}-\mathrm{C}_{2} \mathrm{H}_{5} \mathrm{OH}$ derived from condensation reactions of the resin terminal groups were desaturated, coarsened and rose up to surface during the heating. Such a structure solidified in the middle of the bubble rising process. A ceramic body with hierarchical, nano-meso-porosity was synthesized by Colombo et al. [40]. In the reported process, mesoporous silica was deposited on the Si-O-C microporous ceramics derived from Wacker-Belsil PMS $\mathrm{MK}^{\mathrm{TM}}$ and PMMA microbeads. Deposition of mesoporous silica coating on the Si-O-C wall was carried out by infiltration and pyrolysis of solution of tetraethyl orthosilicate (TEOS) and block copolymer. The resulting specific surface area was one order of magnitude higher than that in previous Si-O-C porous ceramics.

Silicone resins are thus able to accept various kinds of fillers, plasticizers, blowing agents and cross-linking agents. Control of cell size, density and connectivity of foamed cells are intrinsically possible by using various methods developed in the plastic foaming industry field. The reported excellent dimensional stability after the pyrolysis is possibly based on the thermosetting nature and high ceramic yield of the silicones with dense Si-O cross-links.

On the other hand, heat resistance of the resulting Si-O-C porous bodies is a difficult problem to be summarized simply. If additional organic agents were completely burned out during the pyrolysis, the resulting heat resistance would be high. Rouxel et al. evaluated high temperature viscosity of Si-O-C amorphous materials from bending creep displacement of thin small rods with no significant defects. The estimated viscosity values were two orders of magnitude higher than that of pure silica [41]. The carbon content in the Si-O-C amorphous was higher, and the resulting viscosity was higher. Incorporation of carbon in silica-like network is thought to be key factor, which inhibits the viscous flow of the silica-like networks [41-43]. Besides the carbon network, progress of the crystallization of $\beta-\mathrm{SiC}$ and $\beta-\mathrm{SiO}_{2}$ in the $\mathrm{Si}-\mathrm{O}-\mathrm{C}$ matrix harden the materials significantly. In addition, the formation of a protective silica layer on the Si-O-C surface is expected to prevent rapid oxidation.

If the organic additives were to remain in the pyrolyzed materials, however, carbon domains derived from the additives may cause carbon rich domains in the pyrolyzed Si-O-C. Carbon rich domains often diminish the oxidation resistance by breaking the protective silica layer, or diminish the high temperature strength in an inner atmosphere by promoting the evolution of $\mathrm{CO}$ and $\mathrm{SiO}$. If the starting precursor contains $\mathrm{SiC}$ grains, however, the reaction between $\mathrm{Si}-\mathrm{O}-\mathrm{C}$ and carbon domains may promote a sintering-binding process of the $\mathrm{SiC}$ fillers during the pyrolysis process. Perhaps, the upper limit of heat or environmental resistance of the pyrolyzed materials varies depending on the intrinsic chemical compositions and resulting microstructures.

Blends of silicones with ordinary ceramic precursors, like polycarbosilanes, polysilazanes and polysilanes, are another interesting theme. For example, polycarbosilane (PCS), which is famous as a precursor of continuous silicon carbide base fibers, accepts the dissolution of various silicone oils $[44,45]$. Since main chain structure of silicones ( $\mathrm{Si}-\mathrm{O}-\mathrm{Si})$ is different from the chain structure of PCS ( $\mathrm{Si}-\mathrm{CH}_{2}-\mathrm{Si}$ ), compatibility of the silicone oils to PCS is intrinsically limited. Up to $10 \mathrm{mass} \%$, however, the oils act as plasticizers of the prepared blend polymer melts [Figure 5(a)]. Polymethylphenylsiloxane (PMPhS) addition shows the most remarkable plasticizer effect, which diminishes the macromolecular interactions between the polymer chains. On the other hand, the 
plasticizer effect of polymethylhydrosilixoane (PMHS) is limited because of decomposition of Si-H group during the heating. Continuous micro tubes, however, can be spun from the polymer melt by adjusting the $\mathrm{H}_{2}$ gas evolution, dissolution and desaturation processes in the melts. The synthesis of such micro tube is positioned as a unique and extreme case of the precursor polymer foaming process reviewed in previous sections. The spun micro tubes can be converted to $\mathrm{SiC}$ base micro tubes by the pyrolysis at $1273 \mathrm{~K}$ [Figure 5 (b)]. The process deeply depends on Si-H content in PMHS. Since the major precursor used in this system is PCS, high heat resistance is expected on the pyrolyzed micro tubes.

Figure 5. (a) Viscosity - temperature relationship of the polymer blends; PCS: polycarbosilane, HS15: PMHS 15 mass \%to PCS, Hsa15: PMHSa (PMHS with low Si-H content) 15 mass \%to PCS, PS15: PMPhS 15 mass \%to PCS; (b) Silicon carbide base micro tubes derived from melt - spun polymer blend of polycarbosilane-polymethylhydro siloxane) (from the Ph.D. thesis of K. Kita, Osaka Prefecture University, 2010).
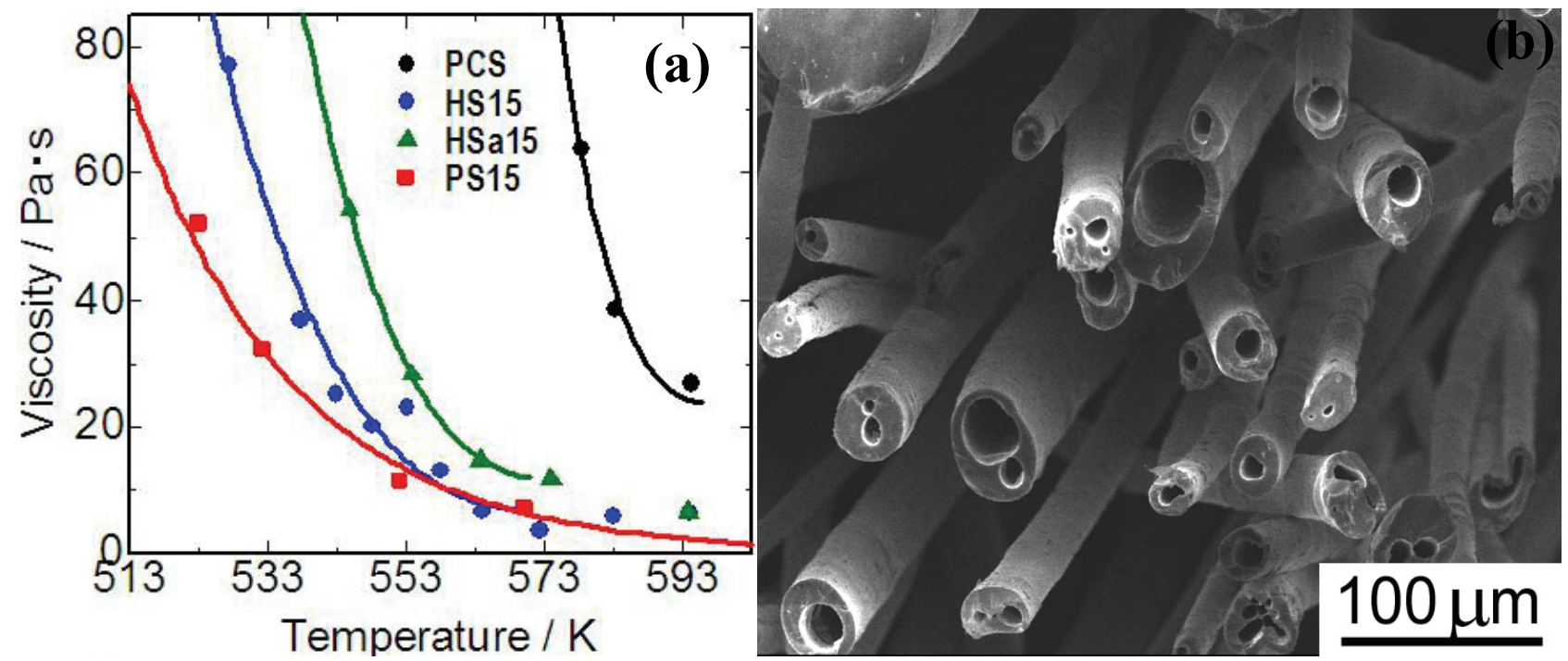

As a quite recent topic, piezoresistive effect in Si-O-C ceramics derived from PMS MK ${ }^{\mathrm{TM}}$ after $1,400{ }^{\circ} \mathrm{C}$ pyrolysis is reported by Riedel et al. [46]. The high strain sensitivity suggests the change of percolation network of excess carbon during the strain application. Perhaps, silicone resin application for ceramic precursor is not limited in the field of structural ceramics. The unique electrical properties of the pyrolyzed Si-O-C materials will be applied for functional ceramics.

\section{Modification of Silicone Resins for Advanced Ceramic Precursors}

The advanced science and technology in modern synthesis chemistry contribute to the production of various promising ceramic precursors with tailored compositions and unique molecular structures. In the plastics industry, however, it is notable that the various kinds of useful materials are produced from limited kinds of conventional polymers. Selection of additive, filler, blend technique and control of the cross-linking process are particularly important to produce materials with excellent properties at reduced cost. In spite of the absolute importance, systematic study of such basic techniques on using silicone resin as ceramic precursor is still at a quite early stage of progress. 
Greil proposed the notion of "active fillers" in the field of the ceramic precursors. The basic idea is trapping of carbon and nitrogen from the surrounding matrix or the gaseous atmosphere by dispersed fillers [47]. The volume of the fillers increases during such carbonization-nitrogenation reactions, which compensates for the volume shrinkage of the surrounding matrix. In the reported successful cases, $\mathrm{CrSi}_{2}$ or $\mathrm{MoSi}_{2}$ powders are dispersed in a kind of poly(silsesquioxane) having $\mathrm{C}_{6} \mathrm{H}_{5}$, $\mathrm{CH}_{2}=\mathrm{CH}-, \mathrm{CH}_{3}$ - and $\mathrm{H}$ - side groups, and the mixed materials are pyrolyzed up to $1,500{ }^{\circ} \mathrm{C}$ in an nitrogen gas flow.

$\mathrm{SiOC}_{\mathrm{x}}$ (High carbon amorphous) $+\mathrm{CrSi}_{2}+2 \mathrm{~N}_{2}$ (in the atmosphere) $\rightarrow \quad 2 / 3 \mathrm{Cr}_{3} \mathrm{C}_{2}$

$+\mathrm{Si}_{3} \mathrm{~N}_{4}+\mathrm{SiOC}_{\mathrm{y}}$ (Low carbon amorphous)

$\mathrm{SiOC}_{\mathrm{x}}$ (High carbon amorphous) $+\mathrm{MoSi}_{2}+2 \mathrm{~N}_{2}$ (in the atmosphere) $\rightarrow 1 / 2 \mathrm{Mo}_{2} \mathrm{C}$

$+\mathrm{Si}_{3} \mathrm{~N}_{4}+\mathrm{SiOC}_{\mathrm{y}}$ (Low carbon amorphous)

During the pyrolysis, silicon in the fillers is converted to $\mathrm{Si}_{3} \mathrm{~N}_{4}$, while chromium and molybdenum in the fillers are converted to $\mathrm{Cr}_{3} \mathrm{C}_{2}$ and $\mathrm{Mo}_{2} \mathrm{C}$, respectively. The carbon content in the starting matrix polymer is not defined precisely, but the absolute amount is sufficient to carbonize chromium and molybdenum by the evolved hydrocarbon gaseous compounds during the pyrolysis. This method is available in principal not only for silicones, but also for carbosilane (Si-C) or silazane (Si-N) backbone precursors.

On the other hand, it is easily predictable that trapping of oxygen from the surrounding silicone resin matrix is probably possible, if the reducing power of the selected filler is sufficiently high. In spite of the simplicity, however, there are not many practical examples based on such ideas. Colombo et al. reported the joining of $\mathrm{SiC} / \mathrm{SiC}$ composites by the combination of SR350 and 88Al-12Si metal powder [48]. The importance of the Al-Si melting for increasing the joint strength and formation of $\mathrm{Al}_{2} \mathrm{O}_{3}$ and $\mathrm{SiC}$ at low temperature region are suggested. The observed shear strength exceeds that of merely pyrolyzed SR350 joined materials and the highest shear strength is observed at $1,200{ }^{\circ} \mathrm{C}$ heat treatment. The concrete characterization of the formed phases during pyrolysis, however, is absent in the written article.

Recently, our group investigated the ceramization process of the YR3370-metal Al particle composites [49]. When the YR3370 resin is simply pyrolyzed in an inert atmosphere, the resin is converted to $\mathrm{SiO}_{1.5} \mathrm{C}_{0.68}$ amorphous up to $1,000{ }^{\circ} \mathrm{C}$. XRD patterns of the pyrolysis products suggest that the $\mathrm{SiC}$ formation proceeds at $1,400{ }^{\circ} \mathrm{C}$ with no significant mass loss. In theory the thermodynamically stable phase derived from $\mathrm{SiO}_{1.5} \mathrm{C}_{0.68}$ is a mixture of $\mathrm{SiO}_{2}, \mathrm{SiC}$ and free carbon:

$$
\mathrm{SiO}_{1.5} \mathrm{C}_{0.68} \rightarrow 0.75 \mathrm{SiO}_{2}+0.25 \mathrm{SiC}+0.43 \mathrm{C}
$$

In spite of the reduced carbon content in the starting silicone resin, the formed material contains a considerable amount of free carbon. In the pyrolysis of the resin - Al composite, the ceramizaton proceeds at quite low temperature, as shown in the corresponding XRD patterns [Figures 6(a) and (b)]. $\mathrm{Al}_{2} \mathrm{O}_{3}, \mathrm{SiC}$ and free $\mathrm{Si}$ formation at $800{ }^{\circ} \mathrm{C}$ can be explained by the following equation:

$$
\mathrm{SiO}_{1.5} \mathrm{C}_{0.68}+\mathrm{Al} \rightarrow 0.68 \mathrm{SiC}+0.5 \mathrm{Al}_{2} \mathrm{O}_{3}+0.32 \mathrm{Si}
$$

In this case, the thermodynamically stable phases must contain free silicon instead of free carbon. We remember the classic thermite process from the observed phase combination, but the absolute 
temperature does not show sharp rise during the heat treatment. Perhaps, the maintained organic nature of the surrounding silicone resin matrix plays an important role for promoting the low temperature ceramization. It is also curious that free silicon and $\mathrm{Al}_{4} \mathrm{C}_{3}$ are observed at $661{ }^{\circ} \mathrm{C}$ with disappearance of aluminum metal, while $\mathrm{Al}_{2} \mathrm{O}_{3}$ and $\mathrm{SiC}$ are absent in XRD patterns. Amorphous $\mathrm{Al}$ oxide formation, metallic liquid phase formation with eutectic Si-Al composition or disproportionation reaction in the $\mathrm{Si}-\mathrm{O}-(\mathrm{C})$ matrix is considerable mechanism for explaining the free $\mathrm{Si}$ formation. Identification of a clear mechanism, however, requires further study.

Figure 6. (a) Dried gel sheets derived from the silicone resin $\left(\mathrm{YR} 3370^{\mathrm{TM}}\right)$ and $3 \mu \mathrm{m} \mathrm{Al}$ particles (Al/Si molar ratio of 1.0), (b) XRD patterns of composite gel sheet during pyrolysis.
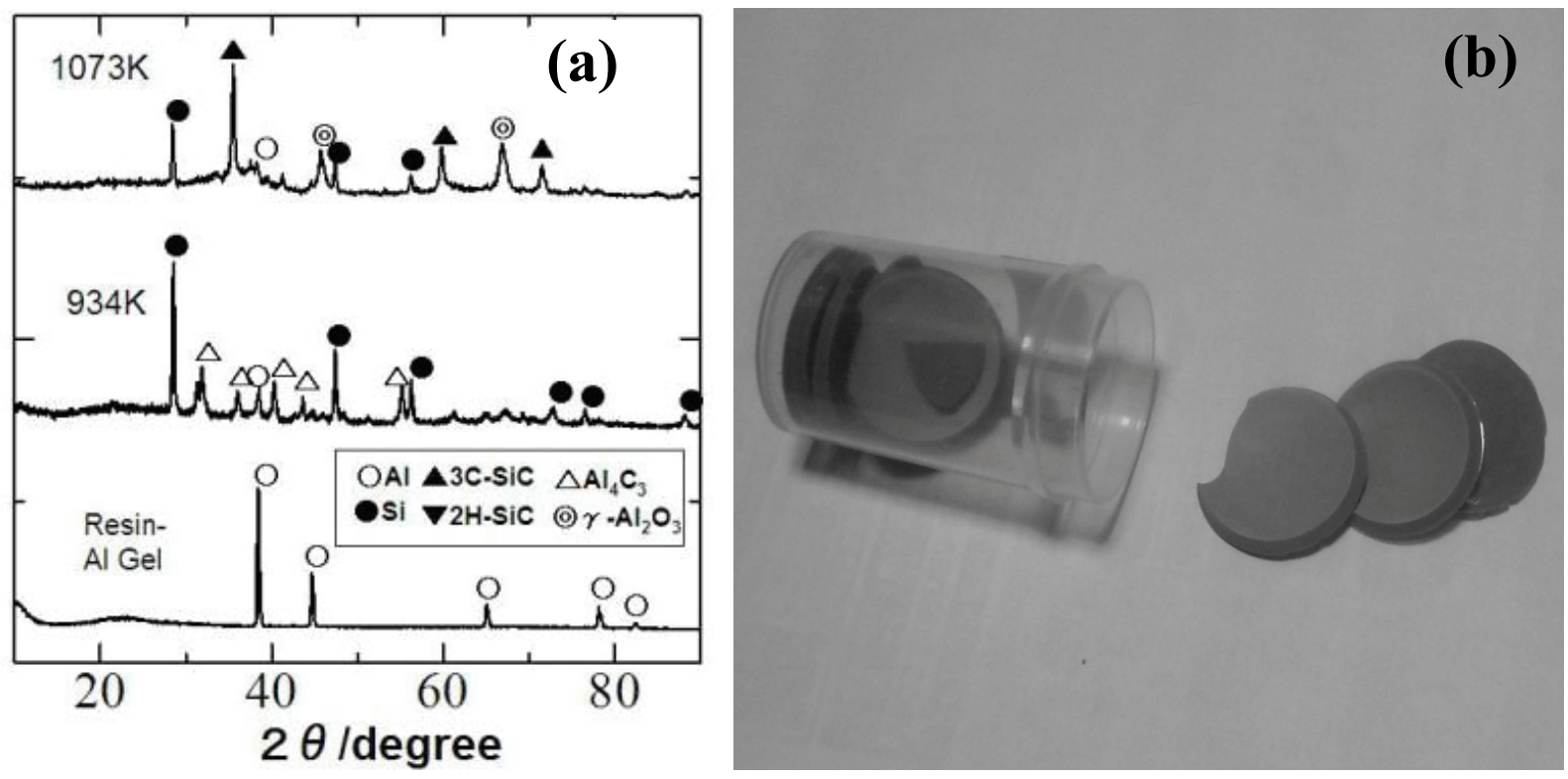

The unique properties of the nano scale interface between pyrolyzed silicone resins and nano size powders are now becoming apparent. Riedel et al. demonstrated mullite phase formation at $1,300-1,500{ }^{\circ} \mathrm{C}$ in the case of a Wacker-Belsil PMS $\mathrm{MK}^{\mathrm{TM}}$ and $\gamma$-alumina combination. This temperature region is far lower than temperature of liquid phase formation in $\mathrm{SiO}_{2}-\mathrm{Al}_{2} \mathrm{O}_{3}$ system. By chemical modification of the nano alumina surface, mixing, warm pressing and pyrolysis in an inert atmosphere, nano composites of alumina (60-160 nm) and silicon carbide (1-8 nm) were successfully obtained. Ionescu et al. reported that incorporation of a large amount of zirconia nano powder in $\mathrm{Si}-\mathrm{O}-\mathrm{C}$ matrix remarkably suppressed degradation process of the synthesized composites at $1,600{ }^{\circ} \mathrm{C}$, which is caused by carbothermal reduction and crystallization processes [23]. A detailed mechanism is not defined, but some chemical interaction is suggested for $\mathrm{Si}$ atoms in $\mathrm{Si}-\mathrm{O}-\mathrm{C}$ and $\mathrm{Zr}$ atoms in zirconia. Even in such "passive oxide filler" cases, it is certain that interface can become "active" under some chemical or physical conditions.

Since commercialized silicone resins with high ceramic yield usually conserve some amount of silanol groups in their molecular structures, the resins often accept chemical modification by various alkoxides. The uses of the alkoxides as cross-linking agents guarantee the atomic level distribution of introduced elements in the starting resin networks, and homogeneous structure evolution during the pyrolysis is expected. In particular, high temperature properties of pyrolyzed materials, like oxidation 
resistance, corrosion resistance or creep resistance, are probably influenced by additional elements. In the case of the $\mathrm{Al}$ alkoxide addition in the PMS $\mathrm{MK}^{\mathrm{TM}}$, the alkoxide acts as a cross-linking agent and suppresses the crack formation process during the pyrolysis [26]. In the high temperature region, $1,200-1,600{ }^{\circ} \mathrm{C}$, the role of $\mathrm{SiO}_{2}-\mathrm{Al}_{2} \mathrm{O}_{3}$ liquid phase formation for reduced cracking is suggested. $\mathrm{Zr}\left(\mathrm{O}^{\mathrm{n}} \mathrm{Pr}\right)_{4}$ is also effective as a cross-linking agent, and nano domains of zirconia were successfully dispersed in the Si-O-C matrix after pyrolysis [23]. High temperature stability at $1,600{ }^{\circ} \mathrm{C}$ was also improved. A high $\mathrm{Zr}$ amount was, however, required even in this case.

\section{Summary}

In this review, I have tried to classify the various silicone resins. The most important feature is the main chain structure of the original silicones, because the ceramic yield of the silicone resin depends on the rate of cyclic oligomer expulsion during the heating. The second point is the resulting chemical composition of the pyrolysis products. The balance of the formed phases $(\mathrm{SiC}, \mathrm{SiO}-\mathrm{CO}$, free carbon and $\mathrm{SiO}_{2}$ ) and the microstructure after the simple pyrolysis are determined by the chemical composition of $\mathrm{SiC}_{\mathrm{x}} \mathrm{O}_{\mathrm{y}}$ amorphous. The third point is the viscoelastic natures of the prepared silicones. Usually, the silicone resins are viscous liquids and often accept cross-links. The obtained resins or cross-linked elastomer can accept relatively high extension without cracks as compared with ordinary ceramic precursors, like polycarbosilane, polysilazane and polysilanes. This character is useful to shape the starting materials into desired forms by molding, casting, injection, impregnation or extrusion. Shape stability during pyrolysis is also promising, if the chain migration is permitted at least locally even during the pyrolysis.

The high carbon or high oxygen contents in silicone resins have been thought to decrease the heat resistance of the resulting $\mathrm{SiO}_{\mathrm{x}} \mathrm{C}_{\mathrm{y}}$ amorphous. Even in an inert atmosphere, degradation of the amorphous proceeds with $\mathrm{CO}-\mathrm{SiO}$ evolution beyond $1,400{ }^{\circ} \mathrm{C}$. Recently, however, the adverse effect of such excess carbon and oxygen can be reduced principally by using the special fillers or crosslinking agents as described.

In spite of their undoubted usefulness, silicone resins have been described as supporting players in ceramic synthesis processes. I wish that this review will provide readers with some knowledge of the various silicone resin natures from the viewpoints of the polymer science and inorganic chemical reaction. Silicone resins are old and classic materials developed at the early years of the 20th century. The materials, however, hold hidden potential even at present, and are possibly key materials in the 21 st century for promoting the precursor method availability in wide industrial applications.

\section{Acknowledgements}

I thank to Young-Wook Kim (The University of Seoul) for information about physical and mechanical properties of YR3370 ${ }^{\mathrm{TM}}$ resin. A part of the content in this article about the Si-O-C fiber synthesis is supported by a Grant in Aid for Scientific Research C (No. 20560627) from Japan Society of Promotion Science. 


\section{References}

1. Yajima, S.; Hayashi, J.; Omori, M. Continuous silicon carbide fiber of high tensile strength. Chem. Lett. 1975, 931-934.

2. Yajima, S.; Hayashi, J.; Omori, M.; Okamura, K. Development of a silicon carbide fibre with high tensile strength. Nature 1976, 261, 683-685.

3. Whitmarsh, C.K.; Interrante, L.V. Synthesis and structure of a highly branched polycarbosilane derived from (chloromethyl)trichlorosilane. Organometallics 1991, 10, 1336-1344.

4. Riedel, R.; Kienzle, A.; Dressler, W.; Ruwisch, L.; Bill, J.; Aldinger, F. A silicoboron carbonitride ceramic stable to 2,000 degrees C. Nature 1996, 382, 796-798.

5. Lipowitz, J.; Rabe, A.; Zangvil, A.; Xu, Y. Structure and properties of sylamic ${ }^{\mathrm{TM}}$ silicon carbide fiber-a polycrystalline stoichiometric $\beta-\mathrm{SiC}$ composition. Ceram. Eng. Sci. Proc. 1997, 18, $147-157$.

6. Ishikawa, T.; Kohtoku, Y.; Kumagawa, K.; Yamamura, T.; Nagasawa, T. High-strength alkali-resistant sintered SiC fibre stable to 2,200 degrees C. Nature 1998, 391, 773-775.

7. Takeda, M.; Sakamoto, J.; Imai, Y.; Ichikawa, H. Thermal stability of the low-oxygen-content silicon carbide fiber, hi-nicalon (TM). Composite Sci. Technol. 1999, 59, 813-819.

8. Okamura, K.; Shimoo, T.; Suzuya, K.; Suzuki, K. SiC-based ceramic fibers prepared via organicto-inorganic conversion process - a review. J. Ceram. Soc. Jpn. 2006, 114, 445-454.

9. Tamura, K. Organosilane; Organosiloxane; Industrial production of silicone; In Yuki Keiso Jushi (Organosilicon Resin, Lecture of Plastic Materials); Nikkan Kogyo Shimbun, Ltd.: Chiyoda-Ku, Japan, 1961; Volume 6, pp. 2-37, pp. 153-173.

10. Rochow, E.G. Discovery of the other half of silicon chemistry, and its consequence; Necessity as the mother of invention: The development of practical silicone polymers in answer to industrial need; Liberation from magnesium; In Silicon and Silicones; Springer-Verlag: Heidelberg, Germany, 1987; pp. 40-90.

11. Yim, A.; Pierre, L.E., St. The effect of filler surface energy on the $T_{g}$ of silicapolydimethylsiloxane composites. J. Polym. Sci. B 1969, 8, 237-239.

12. Polmanteer, K.E.; Hunter, M.J. Holms, D.R.; Bumm, C.W.; Smith, D.I. Polymer composition versus low-temperature characterization of polysiloxane elastomers. J. Appl. Polym. Sci. 1959, 1, $3-10$.

13. Thomas, T.H.; Kendrick, T.C. Thermal analysis of polydimethylsiloxnaes. I. Thermal degradation in controlled atmospheres. J. Polym. Sci. Part A-2 1969, 7, 537-549.

14. Camino, G.; Lomakin, S.M.; Lazzari, M. Polydimethylsiloxane thermal degradation part 1. kinetic aspects. Polymer 2001, 42, 2395-2402.

15. Thomas, T.H.; Kendrick, T.C. Thermal Analysis of polysiloxanes. II. Thermal vacuum degradation of polysiloxanes with different substituents on silicon and in the main siloxane chain. J. Polym. Sci. Part A-2, 1970, 8, 1823-1830.

16. Deshpande, G.; Rezac, M.E. The effect of phenyl content on the degradation of poly(dimethyl diphenyl) siloxane copolymers. Polym. Degrad. Stab. 2001, 74, 363-370.

17. Zhou, W.; Yang, H.; Guo, X.; Lu, J. Thermal degradation behaviors of some branched and linear polysiloxanes. Polym. Degrad. Stab. 2006, 91, 1471-1475. 
18. Mantz, R.A.; Jones, P.F.; Chaffee, K.P.; Lichtenhan, J.D.; Ismail, I.M.K.; Gilman; J.W.; Burmeister, M.J. Thermolysis of Polyhedral Oligometric Silsesquioxane (POSS) Macromers and POSS-Siloxane copolymers. Chem. Mater. 1996, 8, 1250-1259.

19. Burns, G.T.; Taylor, R.B.; Xu, Y.; Zangvil, A.; Zank, G.A. High-temperature chemistry of the conversion of siloxanes to silicon-carbide. Chem. Mater. 1992, 4, 1313-1323.

20. Hurwitz, F.I.; Heimann, P.; Farmer, S.C.; Hembree, D.M., Jr. Characterization of the pyrolytic conversion of polysilsesquioxanes to silicon oxycabides. J. Mater. Sci. 1993, 28, 6622-6630.

21. Brewer, C.M.; Bujalski, D.R.; Parent, V.E.; Su, K.; Zank, G.A. Insights into the oxidation chemistry of SiOC ceramics derived from silsesquioxanes. J. Sol-Gel Sci. Technol. 1999, 14, 49-68.

22. Wilson, A.M.; Zank, G.; Eguchi, K.; Xing, W.; Yates, B.; Dahn, J.R. Polysiloxane pyrolysis. Chem. Mater. 1997, 9, 1601-1606.

23. Ionescu, E.; Linck, C.; Fasel, C.; Muller, M.; Kleebe, H.-J.; Riedel, R. Polymer-derived $\mathrm{SiOC} / \mathrm{ZrO}_{2}$ ceramic nanocomposites with excellent high-temperature stability. J. Am. Ceram. Soc. 2010, 94, 241-250.

24. Suminoe, T.; Matsumura, Y.; Tomomitsu, N. Methylpolysiloxane. Japan Patent S53-88099, 1978.

25. Baney, R.H.; Itoh, M.; Sakakibara, A.; Suzuki, T. Silsesquioxanes. Chem. Rev. 1995, 95, 1409-1430.

26. Harshe, R.; Balan, C.; Riedel, R. Amorphous Si(Al)OC ceramics from polysiloxanes: Bulk ceramic processing, crystallization behavior and applications. J. Eur. Ceram. Soc. 2004, 24, 3471-3482.

27. Kim, Y.W.; Park, C.B. Processing of closed-cell silicon oxycarbide foams from precerramic polymer. J. Mater. Sci. 2004, 39, 5647-5652.

28. Wang, C.-M.; Wang, J.; Park, C.-B.; Kim, Y.W. Fabrication of cellular and microcellular ceramics with controllable open-cell content from polysiloxane-LDPE blends: I. compounding and foaming. J. Mater. Sci. 2007, 42, 2854-2861.

29. Narisawa, M.; Sumimoto, R.; Kita, K.; Kado, H.; Mabuchi, H.; Kim, Y.W. Melt spinning and metal chloride vapor curing process on polymethylsilsesquioxane as Si-O-C fiber precursor. J. Appl. Polym. Sci. 2009, 114, 2600-2607.

30. Narisawa, M.; Yasuda, H.; Mori, R.; Mabuchi, H.; Oka, K.; Kim, Y.W. Silicon carbide particle formation from carbon black-polymethylsilsesquioxane mixtures with melt pressing. J. Ceram. Soc. Jpn. 2008, 116, 121-125.

31. Ma, J.; Shi, L.; Shi, Y.; Luo, S.; Xu, J. Pyrolysis of polymethylsilsesquioxane. J. Appl. Polym. Sci. 2002, 85, 1077-1086.

32. Renlund, G.M.; Prochazka, S.; Doremus, R.H. Silicon oxycarbide glasses: Part I. Preparation and chemistry. J. Mater. Res. 1991, 6, 2716-2722.

33. Renlund, G.M.; Prochazka, S.; Doremus, R.H. Silicon oxycarbide glasses: Part II. Structure and properties. J. Mater. Res. 1991, 6, 2723-2734.

34. Hurwitz, F.I.; Hyatt, L.; Gorecki, J.; D'Amore, L. Silsesquioxanes as precursors to ceramic composites. Ceram. Eng. Sci. Proc. 1987, 8, 732-743.

35. Hurwitz, F.I.; Gyekenyesi, J.Z.; Conroy, P.J. Polymer derived Nicalon/Si-C-O composites: Processing and mechanical behavior. Ceram. Eng. Sci. Proc. 1989, 10, 750-763. 
36. Colombo, P.; Modesti, M. Silicon oxycarbide ceramic foams from a preceramic polymer. J. Am. Ceram. Soc. 1999, 82, 573-578.

37. Kim, Y.-W.; Kim, S.-H.; Wang, C.; Park, C.-B. Fabrication of microcellular ceramics using gaseous carbon dioxide. J. Am. Ceram. Soc. 2003, 86, 2231-2233.

38. Colombo, P.; Bernardo, E.; Biasetto, L. Novel microcellular ceramics from a silicone resin. novel microcellular ceramics from a silicone resin. J. Am. Ceram. Soc. 2004, 87, 52-54.

39. Zeschky, J.; Höfner, T.; Arnold, C.; Weißmann, R.; Bahloul-Hourlier, D.; Scheffler, M.; Greil, P. Polysilsesquioxane derived ceramic foams with gradient porosity. Acta Materialia 2005, 53, 927-937.

40. Costacurta, S.; Biasetto, L.; Pippel, E.; Woltersdorf, J.; Colombo, P. Hierachical porosity components by infiltration of a ceramic foam. J. Am. Ceram. Soc. 2007, 90, 2172-2177.

41. Rouxel, T.; Soraru, G.D., Vicens, J. Creep viscosity and stress relaxation of gel-derived silicon oxycarbide glasses. J. Am. Ceram. Soc. 2001, 84, 1052-1058.

42. Soraru, G.D.; Pederiva, L.; Latournerie, J.; Raj, R. Pyrolysis kinetics for the conversion of a polymer into an amorphous silicon oxycarbide ceramic. J. Am. Ceram. Soc. 2002, 85, 2181-2187.

43. Saha, A.; Raj, R.; Williamson, D.L. A model for the nanodomains in polymer-derived SiCO. J. Am. Ceram. Soc. 2006, 89, 2188-2195.

44. Kita, K.; Narisawa, M.; Mabuchi, H.; Itoh, M.; Sugimoto, M.; Yoshikawa, M. Formation of continuous pore structures in Si-C-O fibers by adjusting the melt spinning condition of a polycarbosilane - polysiloxane polymer blend. J. Am. Ceram. Soc. 2009, 92, 1192-1197.

45. Kita, K.; Narisawa, M.; Nakahira, A.; Mabuchi, H.; Itoh, M.; Sugimoto, M.; Yoshikawa, M. Hightemperature pyrolysis of ceramic fibers derived from polycarbosilane-polymethyl hydrosiloxane polymer blends with porous structures. J. Mater. Sci. 2010, 45, 139-145.

46. Riedel, R.; Toma, L.; Janssen, E.; Nuffer, J.; Melz, T.; Hanselka, H. Piezoresistive effect in SiOC ceramics for integrated pressure sensors. J. Am. Ceram Soc. 2010, 93, 920-924.

47. Greil, P. Active-Filler-controlled pyrolysis of preceramic polymers. J. Am. Ceram. Soc. 1995, 78, 835-848.

48. Colombo, P.; Riccardi, B.; Donato, A.; Scarinci, G. Joining of $\mathrm{SiC} / \mathrm{SiC}_{\mathrm{f}}$ ceramic matrix composites for fusion reactor blanket applications. J. Nuclear Mater. 2000, 278, 127-135.

49. Narisawa, M.; Kado, H.; Mabuchi, H.; Kim, Y.-W. Accelerated ceramization of polymethylsilsesquioxane by aluminum based filler reductant. Appl. Organomet. Chem. 2009, doi:10.1002/aoc.1554.

50. Riedel, R.; Toma, L.; Fasel, C.; Miehe, G. Polymer-derived mullite-SiC-based nanocomposites. J. Eur. Ceram. Soc. 2009, 29, 3079-3090.

(C) 2010 by the authors; licensee MDPI, Basel, Switzerland. This article is an Open Access article distributed under the terms and conditions of the Creative Commons Attribution license (http://creativecommons.org/licenses/by/3.0/). 